INOBIS: Jurnal Inovasi Bisnis dan Manajemen Indonesia

Volume 1, Nomor 1, Maret 2018

Ronny Malavia Mardani

\title{
Pengaruh Return On Asset (Roa), Debt To Total Asset (Dta), Cash Ratio, Growth, Dan Firm Sise Terhadap Kebijakan Dividen
}

Ronny Malavia Mardani

Universitas Islam Malang

\begin{abstract}
The purpose of this study is to examine the effect of Return on Assets (ROA), Debt to Total Assets (DTA), Cash Ratio, Growth, and Firm Sise on Dividend Policy. The population in this study is a manufacturing company listed on the Indonesia Stock Exchange period 2013-2016. While the sample of the study was determined by using purposive sampling, which obtained a number of 25 companies that qualify as research samples.

Based on the analysis results can be seen that the Return on Asset (ROA) have a significant positive effect on dividend policy, Debt to Total Asset (DTA) and Cash Ratio (CR) have no significant positive effect on dividend policy. While Growth and Firm Size have no significant negative effect on dividend policy.
\end{abstract}

Key Words: Return on Assets (ROA), Debt to Total Assets (DTA), Cash Ratio, Growth, Firm Size, Dividend Payout Ratio (DPR).

\section{Pendahuluan}

Penelitian ini bermaksud untuk menguji dan menganalisis factor-faktor yang berpengaruh terhadap kebijakan dividen pada perusahaan manufaktur yang terdaftar di Bursa Efek Indonesia. "Salah satu fungsi dari manajemen keuangan adalah menetapkan kebijakan dividen (dividend policy). Kebijakan dividen menentukan pembagian laba antara pembayaran kepada pemegang saham dan investasi kembali perusahaan. Laba ditahan (retained earning) merupakan salah satu sumber dana paling penting untuk membiayai pertumbuhan perusahaan, tetapi dividen merupakan arus kas yang disisihkan untuk pemegang saham". (Weston and Coopeland, 1997:125).

Kapabilitas perusahaan dalam menghasilkan profit adalah salah satu indikator dari kapabilitas perusahaan untuk memberikan dividen, maka dapat dikatakan pula bahwa profitabilitas merupakan faktor penentu bagi perusahaan untuk memberikan dividen (Lintner, 1959). Secara empiris, hubungan antara profitabilitas dengan dividen pernah diteliti oleh Brittain (1966), yang dalam penelitiannya dapat dibuktikan bahwa profitabilitas secara signifikan berpengaruh positif terhadap dividen. Sedang Chasanah (2008) dan Nugroho (2004) dalam penelitiannya dapat membuktikan bahwa Return on Asset (ROA) berpengaruh positif signifikan terhadap kebijakan dividen. Dari hasil penelitian Amalia (2009) juga menyatakan bahwa Return on Aseet (ROA) juga bepengaruh postif signifikan. Namun hasil penelitian Difah (2011) menunjukkan hasil yang kontradiktif dimana Return on Asset (ROA) tidak signifikan berpengaruh terhadap dividen pada perusahaan BUMN yang terdaftar di bursa efek Indonesia tahun 2004-2009.

Hasil penelitian dari Nugroho (2004) menunjukkan bahwa DTA berhubungan negative signifikan dengan dividen. Namun kontradiktif dengan penelitian yang dilakukan oleh Amalia (2009) dalam penelitiannya menyatakan bahwa variabel DTA berpengaruh tidak signifikan terhadap Dividend Payout Ratio (DPR). 
INOBIS: Jurnal Inovasi Bisnis dan Manajemen Indonesia

Volume 1, Nomor 1, Maret 2018

\section{Ronny Malavia Mardani}

Difah (2011) dan Amalia (2009) dalam penelitiannya dapat membuktikan bahwa cash ratio berpengaruh positif signifikan terhadap dividend payout ratio. Hasil penelitian tersebut berbeda dengan hasil penelitian Nugroho (2004) yang menyatakan bahwa variabel cash ratio tidak berpengaruh signifikan terhadap Dividend Payout Ratio (DPR).

Nugroho (2004) dan Latiefasari (2011) menemukan bahwa growth berpengaruh positif signifikan terhadap kebijakan dividen. Hasil ini didukung oleh Difah (2011) yang dalam penelitiannya juga dapat membuktikan hal serupa. Dalam penelitian Amalia (2009) dan Shitta Amalia Growth (2011) berpengaruh negatif signifikan terhadap Dividend Payout Ratio (DPR). Sedangkan Variabel firm size dinyatakan berpengaruh positif signifikan terhadap Dividend Payout Ratio (DPR) pada penelitian Amalia (2009), Difah (2011) dan Amalia (2011). Namun kontradiktif dengan hasil penelitian Nugroho (2004) dimana variabel size berpengaruh tidak signifikan. Variabel debt to equity ratio dinyatakan berpengaruh positif signifikan terhadap Dividend Payout Ratio (DPR) pada penelitian Latiefasari (2011). Akan tetapi, hasil yang berbeda diperoleh Amilia (2011) yang dalam penelitiannya dapat membuktikan bahwa rasio hutang berpengaruh negatif tidak signifikan terhadap kebijakan dividen.

Inkonsitensi hasil-hasil penelitian yang telah diuraikan sebelumnya menjadi dasar untuk dilakukan penelitian kembali faktor-faktor yang mempengaruhi kebijakan dividen, sehingga dari uraian diatas dapat dirumuskan pertanyaan penelitian (research question) : apakah Return on Asset (roa), Debt to Total Asset (dta), Cash Ratio, Growth, dan Firm Size berpengaruh terhadap kebijakan dividen?

\section{Kontribusi Penelitian}

Penelitian ini diharapkan dapat memberikan kontribusi bagi banyak pihak, diantaranya adalah:

1. Bagi akademisi penelitian ini dapat memberikan bukti empiris mengenai faktor-faktor yang berpengaruh terhadap dividend payout ratio sehingga dapat memberikan pengetahuan yang lebih mendalam mengenai kebijakan deviden.

2. Bagi praktisi :

a. Bagi manajemen perusahaan dapat hasil penelitian ini dapat dijadikan pertimbangan dalam menentukan kebijakan deviden.

b. Bagi investor dapat dijadikan sebagai bahan pertimbangan dalam mengambil keputusan penanaman dananya di pasar modal.

\section{Tinjauan teori}

\section{Dividend Payout Ratio (DPR)}

"Dividen merupakan hak pemegang saham biasa (common stock) untuk mendapatkan bagian dari keuntungan perusahaan. Jika perusahaan memutuskan untuk membagi keuntungan dalam dividen, semua pemegang saham biasa mendapatkan haknya yang sama. Pembagian dividen untuk saham biasa dapat dilakukan jika perusahaan sudah membayar dividen untuk saham preferen (Jogiyanto, 1998:58)". Basri dan Gitosudarmo (2000:244) juga mengatakan bahwa "DPR merupakan ratio antara dividend per share dengan earning per share. Dividend Payout Ratio (DPR) mencerminkan kebijakan deviden dari manajemen mengenai besarnya dividen yang harus dibayarkan kepada pemegeng saham. Secara sistematis DPR dapat dirumuskan sebagai berikut: $\mathrm{DPR}=\frac{D P S}{E P S}$, 
INOBIS: Jurnal Inovasi Bisnis dan Manajemen Indonesia

Volume 1, Nomor 1, Maret 2018

Ronny Malavia Mardani

\section{Return on Asset (ROA)}

"Return on Asset (ROA) adalah salah satu ukuran (profitabiltas) merupakan ukuran efektifitas perusahaan dalam menghasilkan keuntungan dengan memanfaatkan asset yang digunakan untuk operasi. Semakin besar ROA menunjukkan kinerja perusahaan semakin baik, karena tingkat pengembalian investasi (return) semakin besar. Secara matematis ROA dapat dirumuskan sebagai berikut: $\mathrm{ROA}=\frac{E A T}{\text { TOTAL ASET }} \cdot$ "(Brigham dan Houston, 2015)

\section{Debt to Total Asset (DTA)}

"Debt to Total Asset merupakan ratio antara total hutang (total debts) baik hutang jangka pendek (current liability) dan hutang jangka panjang terhadap total aktiva (total assets) baik aktiva lancar (current assets) maupun aktiva tetap (fixed asset) dan aktiva lainnya (others assets). Rasio ini menunjukkan besarnya hutang yang digunakan untuk membiayai aktiva yang digunakan oleh perusahaan dalam rangka menjalankan aktivitas operasionalnya. Semakin besar debt ratio menunjukkan semakin besar tingkat ketergantungan perusahaan terhadap pihak eksternal dan semakin besar pula beban biaya hutang yang harus dibayar oleh perusahaan" (Brigham dan Houston, 2015). "Semakin meningkatnya debt ratio berdampak terhadap profitabilitas yang diperoleh perusahaan, karena sebagian digunakan untuk membayar bunga pinjaman. Biaya bunga yang semakin besar, maka profitabilitas (earning after tax) semakin berkurang (karena digunakan untuk membayar bunga), maka hak para pemegang saham (dividend) juga semakin berkurang atau menurun. Secara matematis DTA dapat dirumuskan sebagai berikut: DTA $=\frac{\text { TOTAL DEBT }}{\text { TOTAL ASSET }},($ Ang,1997).

\section{Cash Ratio}

"Cash ratio merupakan salah satu ukuran dari rasio likuiditas (liquiditas ratio) yang merupakan kemampuan perusahaan memenuhi kewajiban jangka pendeknya (current liability) melalui sejumlah kas (dan setara kas, seperti giro atau simpanan lain di bank yang dapat ditarik setiap saat) yang dimiliki perusahaan. Semakin tinggi cash ratio menunjukkan kemampuan kas perusahaan untuk memenuhi kewajiban jangka pendeknya". Secara matematis Cash Ratio dapat dirumuskan sebagai berikut : Cash Ratio $=\frac{\text { Cash +Equivalent }}{\text { Current Liability }}$. "(Brigham dan Houston, 2015)

Kas dan ekuivalennya menunjukkan besarnya kas dan setara kas (giro dan simpanan lain yang pengambilannya tidak dibatasi oleh waktu) yang tercermin dalam neraca (sisi asset/current asset). Sedangkan Current liability menentukan jumlah kewajiban jangka pendek yang tercermin dalam neraca (sisi liability/current liability).

\section{Growth}

Teori free cash flow hipothesis yang disampaikan oleh Jensen (1986) dalam Jensen et el (1992) menyebutkan bahwa "perusahaan dengan kesempatan pertumbuhan yang lebih tinggi akan memiliki free cash flow yang rendah karena sebagian besar dana yang ada digunakan untuk investasi pada proyek yang memiliki nilai Net Present Value (NPV) yang positif. Manajer dalam bisnis perusahaan dengan memperhatikan pertumbuhan lebih menyukai untuk menginvestasikan pendapatan setelah pajak dan mengharapkan kinerja dari dividen akan lebih 
INOBIS: Jurnal Inovasi Bisnis dan Manajemen Indonesia

Volume 1, Nomor 1, Maret 2018

Ronny Malavia Mardani

kuat dalam pertumbuhan perusahaan secara keseluruhan (Charitou dan Vafeas, 1998). Secara matematis growth dapat dirumuskan sebagai berikut: Growth $=\frac{\operatorname{Net} \text { Sales }(t)-\operatorname{Net} \text { sales }(t-1)}{\operatorname{Net} \text { sales }(t-1)}$,

\section{Firm Size}

Smith dan Watts (1992) menunjukkan, "dasar teori pada pengaruh dari ukuran perusahaan (Firm Size) terhadap dividend payout ratio sangat kuat. Perusahaan besar dengan akses pasar yang lebih baik seharusnya membayar dividen yang tinggi kepada pemegang sahamnya, sehingga antara ukuran perusahaan dan pembayaran dividen memiliki hubungan yang positif, dimana proksi Size adalah total asset. Secara matematis Size dapat dirumuskan sebagai berikut: Size = Total asset"

\section{Hipotesis}

Hipotesis dalam penelitian dapat dinyatakan sebagai berikut :

H1 : ROA berpengaruh positif terhadap Dividend Payout Ratio.

H2 : DTA berpengaruh negatif terhadap Dividend Payout Ratio.

H3 : Cash Ratio berpengaruh positif terhadap Dividend Payout Ratio.

H4 : Growth berpengaruh negatif terhadap Dividend Payout Ratio.

H5 : Firm Size berpengaruh positif terhadap Dividend Payout Ratio.

\section{Metode penelitian}

\section{Populasi dan Sampel}

Populasi dalam penelitian ini adalah perusahaan-perusahaan manufaktur yang listed di Bursa Efek Indonesia. Sedangkan sampel ditentukan dengan metode purposive sampling dengan kriteria sebagai berikut :

1. Perusahaan manufaktur yang listed di BEI periode tahun 2013-2016.

2. Perusahaan yang membagikan dividen selama empat tahun berturut-turut pada tahun 2013-2016.

3. Perusahaan mempublikasikan laporan keuangan yang telah di audit setiap tahun selama periode tahun 2013-2016.

\section{Definisi Operasionalisasi Variabel}

\section{Kebijakan Dividend}

Kebijakan dividen menyangkut keputusan penggunaan laba bersih (EAT) untuk pembayaran dividen. Kebijakan dividen diproxykan pada Dividend Payout Ratio (DPR). "DPR merupakan rasio antara dividend pershare (DPS) terhadap earning per share (DPS)" (Basri dan Gitosudarmo. 2000:244).

\section{Return on Asset (ROA)}

"Return on Asset (ROA) merupakan rasio antara pendapatan bersih sesudah pajak (Erning After Tax) terhadap total asset yang dinyatakan dalam persen. Rasio ini mengukur kemampuan asset dalam menghasilkan laba bersih" (Brigham dan Houston, 2015) 
INOBIS: Jurnal Inovasi Bisnis dan Manajemen Indonesia

Volume 1, Nomor 1, Maret 2018

Ronny Malavia Mardani

\section{Debt to Total Asset (DTA)}

"DTA merupakan ratio antara total hutang (total debts) baik hutang jangka pendek (current liability) dan hutang jangka panjang terhadap total aktiva (total assets) baik aktiva lancar (current assets) maupun aktiva tetap (fixed asset) dan aktiva lainnya (others assets)" (Ang, 1997).

\section{Cash Ratio}

DTA $=\frac{\text { Total Debt }}{\text { Total Asset }}$

Merupakan rasio antara kas dan equivalent terhadap current liability. Kas dan equivalent menunjukkan besarnya kas dan setarakas (giro dan simpanan lain yang pengambilannya tidak dibatasi oleh waktu), sedangkan current liability menunjukkan jumlah kewajiban jangka pendeknya (Brigham dan Houston, 2015)

\section{Growth}

$$
\text { Cash Ratio }=\frac{\text { Cash }+ \text { Equivalent }}{\text { Currernt Liability }}
$$

Merupakan rasio antara net sales ( $\mathrm{t})$ sekarang dikurangi dengan net sales sebelumnya (t-1) terhadap net sales sebelumnya (t-1) (Ang, 1997).

\section{Firm Size (Ukuran Perusahaan)}

Growth $=\frac{\text { Net Sales }(t)-\text { Net Sales }(t-1)}{\text { Net Sales }(t-1)}$

Ukuran untuk menentukan ukuran perusahaan adalah dari total asset (Smith dan Watts, 1992). Formula yang digunakan : Size $=$ Ln Total asset.

\section{Metode Analisis}

Metode analisis yang dipakai dalam penelitian ini adalah dengan menggunakan analisis regresi linier berganda dengan model persamaan sebagai berikut :

$D P R=a+b_{1} R O A+b_{2} D T A+b_{3} C R+b_{4} G R O W T H+b_{5} F I R M S I Z E+e$

Dimana:

DPR = Dividend Payout Ratio

ROA $\quad=$ Return On Asset

DTA = Debt to Total Asset

CR $\quad=$ Cash Ratio

G $\quad$ Growth

Firm Size = Ukuran Perusahaan

a $\quad=$ konstanta

$b_{1}, b_{2}, b_{3}, b_{4}, b_{5}=$ koefisien regresi

$\mathrm{e} \quad=$ kesalahan residual (error)

\section{Hasil penelitian dan pembahasan}

\section{Sampel Penelitian}

Jumlah saham perusahaan manufaktur yang listed di Bursa Efek Indonesia periode tahun 2013-2016 berjumlah 131 perusahaan. Kriteria sampel dalam penelitian ini adalah perusahaan yang membagikan dividen selama empat tahun berturut-turut pada periode 2013-2016, dan 
INOBIS: Jurnal Inovasi Bisnis dan Manajemen Indonesia

Volume 1, Nomor 1, Maret 2018

\section{Ronny Malavia Mardani}

mempublikasikan laporan keuangan yang telah di audit setiap periode tahun 2013-2016. Sehingga diperoleh sejumlah 25 perusahaan sebagai sampel penelitian.

\section{Statistik Deskriptif}

Berdasarkan input data dari ICMD 2017 maka dapat dihitung rasio-rasio keuangan yang digunkan dalam penelitian ini yang meliputi DPR, ROA, Cash Ratio, Growth, Firm Size.

Selanjutnya apabila dilihat dari nilai minimum, maximum, rata-rata (mean) dan standar deviasi $(\delta)$ dari masing-masing variabel penelitian dapat dilihat pada Tabel 1 berikut ini:

Tabel 1. Descriptive Statistics

\begin{tabular}{|l|c|r|r|r|r|}
\hline & $\mathrm{N}$ & Minimum & Maximum & Mean & Std. Deviation \\
\hline ROA & 100 &, 0127 &, 5676 &, 182276 &, 1245099 \\
\hline DTA & 100 &, 1153 &, 9482 &, 390564 &, 1898482 \\
\hline CR & 100 &, 0240 & 5,1845 &, 867459 & 1,0088758 \\
\hline Growth & 100 &,- 8937 &, 5526 &, 135024 &, 1887340 \\
\hline Firm Size & 100 & 1,53 & 2,09 & 1,8370 &, 11862 \\
\hline DPR & 100 &, 0001 & 3,0294 &, 479400 &, 4162768 \\
\hline
\end{tabular}

Berdasarkan hasil perhitungan pada tabel 1 tersebut nampak bahwa dari 25 perusahaan sampel dengan menggunakan metode pooled dimana perusahaan dikalikan periode tahun pengamatan (4 tahun), sehingga sampel dalam penelitian ini adalah $25 \times 4=100$ sehingga sampel yang di gunakan sejumlah 100. Variabel DPR mempunyai rata-rata sebesar 0,479400 dengan standar deviasi sebesar 0,4162768 dimana nilai standar deviasi lebih kecil dari ratarata DPR. Demikian pula nilai minimum sebesar 0,0001 lebih kecil dari rata-rata DPR dan nilai maksimum sebesar 3,0294 yang lebih besar dari nilai rata-rata DPR. Hasil yang sama juga terjadi pada variabel ROA, DTA dan Firm Size.

Sedangkan variabel Cash Ratio nilai rata-ratanya sebesar 0,867459 dengan standar deviasi sebesar 1,0088758 lebih besar dari nilai rata-rata. Demikian nilai minimum sebesar 0,0240 lebih kecil dari nilai rata-rata dan nilai maksimum sebesar 5,1845 lebih besar dari nilai rata-rata. Hal yang sama terjadi pada Variabel Growth.

\section{Pembahasan}

Untuk membuktikan apakah model regresi linier berganda yang dipergunakan dalam penelitian ini telah memenuhi asumsi klasik, maka selanjutnya akan dilakukan evaluasi ekonometrika. Evaluasi ekonometrika terdiri dari uji normalitas data, multikolinearitas, uji heteroskedastisitas, dan uji autokorelasi.

a. Uji Normalitas

Hasil uji normalitas data dapat disajikan pada Tabel 2 di bawah ini.

Tabel 2. Hasil Uji Normalitas

\begin{tabular}{|c|c|c|c|c|c|c|c|}
\hline & & $\mathrm{ROA}$ & DTA & CR & Growth & $\begin{array}{l}\text { Firm } \\
\text { size }\end{array}$ & DPR \\
\hline $\mathrm{N}$ & & 100 & 100 & 100 & 100 & 100 & 100 \\
\hline $\begin{array}{l}\text { Normal } \\
\text { Parameters(a, }\end{array}$ & Mean & ,182276 & ,390564 & ,867459 &, 135024 & $\begin{array}{r}1,837 \\
0\end{array}$ & ,479400 \\
\hline
\end{tabular}


INOBIS: Jurnal Inovasi Bisnis dan Manajemen Indonesia

Volume 1, Nomor 1, Maret 2018

Ronny Malavia Mardani

\begin{tabular}{|c|c|c|c|c|c|c|c|}
\hline \multicolumn{8}{|l|}{ b) } \\
\hline & $\begin{array}{l}\text { Std. } \\
\text { Deviatio } \\
\mathrm{n}\end{array}$ & $\begin{array}{r}, 124509 \\
9\end{array}$ & $\begin{array}{r}189848 \\
2\end{array}$ & $\begin{array}{r}1,008875 \\
8\end{array}$ & $\begin{array}{r}188734 \\
0\end{array}$ & $\begin{array}{r}, 1186 \\
2\end{array}$ & $\begin{array}{r}, 416276 \\
8\end{array}$ \\
\hline $\begin{array}{l}\text { Most Extreme } \\
\text { Differences }\end{array}$ & Absolute &, 140 & ,105 & 226 &, 161 & , 129 & , 192 \\
\hline & Positive & 140 & , 105 & 226 & ,092 & , 129 & , 192 \\
\hline & Negative &,- 091 &,- 074 &,- 202 &,- 161 &,- 059 &,- 132 \\
\hline \multicolumn{2}{|c|}{ Kolmogorov-Smirnov Z } & 1,400 & 1,051 & 2,255 & 1,606 & 1,291 & 1,922 \\
\hline \multicolumn{2}{|c|}{ Asymp. Sig. (2-tailed) } & ,040 & 219 &, 000 & 012 & ,071 & ,001 \\
\hline
\end{tabular}

Dari hasil uji normalitas terbukti bahwa kelima variabel bebas tersebut ada beberapa variabel yang tidak berdistribusi normal. Walaupun distribusi data tidak seluruhnya berdistribusi normal, namun analisis dengan menggunakan regresi berganda tetap dilanjutkan. Analisi linier berganda memang mensyaratkan adanya data yang berdistribusi normal agar menghasilkan Best Linier Unbiased Estimated (BLUE). Dengan kata lain, agar model tersebut bisa digunakan untuk memprediksi akan menghasilkan estimasi yang tidak bias. Penelitian ini tidak dimaksudkan untuk melakukan estimasi tetapi hanya bertujuan untuk mengidentifikasi ada atau tidak ada pengaruh antara variabel independen terhadap variabel dependen.

b. Uji Multikolinearitas

Berikut ini akan disajikan hasil pengujian multikolinearitas yang dilakukan dengan bantuan SPSS for windows, secara lengkap hasil tersebut dapat dilihat pada tabel 3 berikut:

Tabel 3. Hasil Uji Multikolonieritas

\begin{tabular}{|c|c|c|c|}
\hline Model & & \multicolumn{2}{|c|}{ Collinearity Statistics } \\
\hline & & Tolerance & VIF \\
\hline 1 & (Constant) & & \\
\hline & ROA & 966 & 1,035 \\
\hline & DTA & ,946 & 1,057 \\
\hline & CR & ,929 & 1,077 \\
\hline & Growth & 956 & 1,046 \\
\hline & Firm size & 913 & 1.096 \\
\hline
\end{tabular}

Berdasarkan hasil pengujian multikolinieritas dapat diketahui bahwa secara keseluruhan variabel bebas yang digunakan dalam penelitian ini yang meliputi variabel return on asset, debt to total asset, cash ratio, growth, dan firm size tidak terjadi multikolinearitas (VIF masing-masing variable bebas $<4$ ).

c. Uji Heteroskedastisitas

Hasil uji heteroskedastisitas dapat ditunjukkan dalam tabel 4 sebagai berikut: 
INOBIS: Jurnal Inovasi Bisnis dan Manajemen Indonesia

Volume 1, Nomor 1, Maret 2018

Ronny Malavia Mardani

Tabel 4 Hasil Uji Heteroskedastisitas

\begin{tabular}{|c|c|c|c|c|c|c|}
\hline \multirow[t]{2}{*}{\begin{tabular}{|l} 
Mode \\
1
\end{tabular}} & & \multicolumn{2}{|c|}{$\begin{array}{c}\text { Unstandardized } \\
\text { Coefficients }\end{array}$} & \multirow{2}{*}{$\begin{array}{c}\text { Standardized } \\
\text { Coefficients } \\
\text { Beta }\end{array}$} & \multirow[b]{2}{*}{$\mathrm{t}$} & \multirow[b]{2}{*}{ Sig. } \\
\hline & & B & $\begin{array}{l}\text { Std. } \\
\text { Error }\end{array}$ & & & \\
\hline 1 & (Constant) &,- 068 & ,630 & &,- 107 & ,915 \\
\hline & ROA &,- 004 & 321 &,- 001 &,- 014 & ,989 \\
\hline & DTA &,- 005 & ,213 &,- 002 &,- 022 & ,982 \\
\hline & CR & ,001 & , 040 & ,002 & ,018 & ,985 \\
\hline & Growth & ,001 & ,213 &, 001 & ,006 & ,996 \\
\hline & Firm size & 038 & ,346 &, 012 & ,109 & 913 \\
\hline
\end{tabular}

Berdasarkan tabel 4, tampak bahwa seluruh variabel bebas memiliki nilai sig $\mathrm{t}>0,05$, sehingga dapat disimpulkan bahwa model memenuhi asumsi heteroskedastisitas.

d. Uji Otokorelasi

Hasil uji autokorelasi dapat disajikan pada Tabel 5 berikut:

Tabel 5 Hasil uji autokorelasi

\begin{tabular}{|l|c|r|r|r|r|}
\hline Model & $\mathrm{R}$ & $\begin{array}{c}\mathrm{R} \\
\text { Square }\end{array}$ & $\begin{array}{c}\text { Adjusted R } \\
\text { Square }\end{array}$ & $\begin{array}{c}\text { Std. Error of the } \\
\text { Estimate }\end{array}$ & $\begin{array}{c}\text { Durbin- } \\
\text { Watson }\end{array}$ \\
\hline 1 &, $389(\mathrm{a})$ &, 151 &, 106 &, 3935685 & 1,867 \\
\hline
\end{tabular}

Dari hasil hitung Durbin Watson sebesar 1,867, sedangkan dalam tabel DW untuk $\mathrm{k}=$ 5 dan $\mathrm{N}=100$ besarnya dl (batas luar) $=1,571 ; 4-\mathrm{dl}=2,429$ dan du (batas dalam) $=$ 1,$780 ; 4-\mathrm{du}=2,133$. Sehingga nilai du: 1,780<DW:1,867<4-du:2,133 maka dari perhitungan disimpulkan bahwa DW-test tersebut tidak terjadi autokorelasi.

\section{Pengujian Hipotesis}

a. Goodness of Fit

Goodness of Fit dilakukan dengan menggunakan uji F. Hasil uji F dapat dilihat pada tabel 6 .

Tabel 6 Hasil Perhitungan Regresi Berganda

\begin{tabular}{|l|l|r|r|r|c|c|}
\hline & & Sum of Squares & Df & Mean Square & F & Sig. \\
\hline 1 & Regression & 2,595 & 5 &, 519 & 3,351 &, $008(\mathrm{a})$ \\
\hline & Residual & 14,560 & 94 &, 155 & & \\
\hline & Total & 17,155 & 99 & & & \\
\hline
\end{tabular}

Berdasarkan hasil analisis uji $\mathrm{F}$ pada tabel 6 dengan signifikansi 0,008, sehingga dapat diketahui bahwa tingkat signifikansi lebih kecil dari 5\% dan nilai $\mathrm{F}_{\text {hitug }}=3,351>$ $t_{\text {tabel }}=2,325$. Sehingga dengan demikian dapat disimpulkan bahwa variable bebas yang terdiri dari return on asset, debt to total asset, cash ratio, growth, dan firm size diantaranya memiliki kemampuan untuk mempengaruhi dividend payout ratio. 
INOBIS: Jurnal Inovasi Bisnis dan Manajemen Indonesia

Volume 1, Nomor 1, Maret 2018

Ronny Malavia Mardani

b. Uji t

Secara lengkap hasil uji t dapat disajikan pada tabel 7.

Tabel 7 Hasil Analisis Regresi Linier Berganda

\begin{tabular}{|c|c|c|c|c|c|c|}
\hline \multirow[t]{2}{*}{ Model } & & \multicolumn{2}{|c|}{$\begin{array}{c}\text { Unstandardized } \\
\text { Coefficients }\end{array}$} & \multirow{2}{*}{$\begin{array}{c}\begin{array}{c}\text { Standardized } \\
\text { Coefficients }\end{array} \\
\text { Beta }\end{array}$} & \multirow[t]{2}{*}{$\mathrm{t}$} & \multirow[t]{2}{*}{ Sig. } \\
\hline & & B & Std. Error & & & \\
\hline 1 & (Constant) & ,762 &, 635 & & 1,199 & ,233 \\
\hline & ROA & 1,076 & ,323 & ,322 & 3,329 & ,001 \\
\hline & DTA & ,326 & ,214 & ,148 & 1,520 &, 132 \\
\hline & $\mathrm{CR}$ &, 030 &, 041 &, 073 &, 737 &, 463 \\
\hline & Growth &,- 308 & ,214 &,- 140 & 1,437 &, 154 \\
\hline & Firm size &,- 321 & ,349 &,- 092 &,- 920 & ,360 \\
\hline
\end{tabular}

Berdasarkan hasil analisis regresi linier berganda yang disajikan pada tabel 7 , maka model persamaan regresi berganda adalah sebagai berikut:

DPR = 0,762 + 1,076ROA + 0,326DTA + 0,030CR - 0,308Growth - 0,321Firmsize + e

Dari persamaan regresi linier berganda tersebut diatas maka dapat dianalisis sebagai berikut:

1. Variabel Return on Asset (ROA)

Hubungan ROA dengan DPR unstandardised coefficients yaitu $b_{1}=1,076$ secara statistik terjadi nyata atau berbeda dengan nol dan nilai $t_{\text {hitung }}=3,329>t_{\text {tabel }}$ $=1,946$ dengan signifikan $=0,001<0,05$. Hasil tersebut menunjukkan bahwa adanya pengaruh yang signifikan variabel return on asset terhadap dividend payout ratio pada perusahaan manufaktur yang listed di Bursa Efek Indonesia. Kondisi ini sesuai dengan teori bila terjadi kenaikan ROA maka DPR akan semakin tinggi pula.

Hasil ini penelitian ini konsisten dengan penelitian Nugroho (2004), Chasanah (2008) dan Amalia (2009) bahwa profitabilitas berpengaruh positif signifikan terhadap kebijakan dividen. ROA juga merupakan ukuran efektif perusahaan dalam menghasilkan keuntungan dengan memanfaatkan aktiva tetap yang digunkan untuk operasi.

Dengan hasil ini maka $\mathrm{H}_{1}$ yang menyatakan bahwa Retun on Asset ROA berpengaruh positif terhadap dividend payout ratio (DPR) diterima.

2. Variabel Debt to Total Asset (DTA)

Hubungan DTA dengan DPR unstandardised coefficients yaitu $b_{2}=0,326$ secara statistik terjadi tidak nyata atau tidak berbeda dengan nol dan nilai $t_{\text {hitung }}=$ $1,520<t_{\text {tabel }}=1,946$ dengan signifikan $=0,132>0,005$. Hasil tersebut menunjukkan bahwa tidak adanya pengaruh yang signifikan variabel debt to total asset terhadap dividend payout ratio pada perusahaan manufaktur yang listed di Bursa Efek Indonesia. Hasil ini mendukung penelitian Amalia (2009) bahwa DTA tidak 
INOBIS: Jurnal Inovasi Bisnis dan Manajemen Indonesia

Volume 1, Nomor 1, Maret 2018

Ronny Malavia Mardani

berpengaruh signifikan terhadap DPR. Namun kontradiktif dengan penelitian Nugroho (2004) yang menyatakan DTA berpengaruh signifikan terhadap DPR.

Dengan hasil ini maka $\mathrm{H}_{2}$ yang menyatakan bahwa Debt to Total Asset (DTA) berpengaruh negatif terhadap dividend payout ratio (DPR) diterima.

\section{Variabel Cash Ratio}

Hubungan Cash Ratio dengan DPR unstandardised coefficients yaitu $b_{3}=0,030$ secara statistik terjadi tidak nyata atau tidak berbeda dengan nol dan nilai $t_{\text {hitung }}=$ $0,737<t_{\text {tabel }}=1,946$ dengan signifikan $=0,463>0,05$. Hasil tersebut menunjukkan bahwa tidak adanya pengaruh yang signifikan variabel cash ratio terhadap dividend payout ratio pada perusahaan manufaktur yang listed di Bursa Efek Indonesia. Hasil ini mendukung penelitian dari Nugroho (2004) namun kontradiktif dengan penelitian Amalia (2009) dan Amalia (2011) yang menyatakan berpengaruh signifikan negatif, Difah (2011) yang menyatakan berpengaruh signifikan positif.

Dengan hasil ini maka $\mathrm{H}_{3}$ yang menyatakan bahwa Cash Ratio berpengaruh positif terhadap dividend payout ratio (DPR) diterima.

4. Variabel Growth

Hubungan Growth dengan DPR unstandardised coefficients yaitu $b_{4}=-0,308$ secara statistik terjadi tidak nyata atau tidak berbeda dengan nol dan nilai $t_{\text {hitug }}=-$ $1,437<t_{\text {tabel }}=1,946$ dengan signifikan $=1,54>0,05$. Hasil tersebut menunjukkan bahwa tidak ada pengaruh yang signifikan variabel growth terhadap dividend payout ratio pada perusahaan manufaktur yang listed di Bursa Efek Indonesia. Hasil ini mendukung penelitian Shitta (2011) negatif tidak signifikan namun kontradiktif dengan penelitian Nugroho (2004) yang berpengaruh signifikan, Fira Puspita (2009), Latifasari (2011), yang menyatakan berpengaruh signifikan negatif, Difah (2011) yang menyatakan signifikan positif.

Dengan hasil ini maka $\mathrm{H}_{4}$ yang menyatakan bahwa Growth berpengaruh negatif terhadap dividend payout ratio (DPR) ditolak.

5. Variabel Firm Size

Hubungan Firm Sise dengan DPR unstandardised coefficients yaitu $b_{5}=-0,321$ secara statistik terjadi tidak nyata atau tidak berbeda dengan nol dan nilai $t_{\text {hitug }}=$ $0,920<\mathrm{t}_{\text {tabel }}=1,946$ dengan signifikan $=0,360>0,05$.. Hasil tersebut menunjukkan bahwa tidak adanya pengaruh yang signifikan variabel firm size terhadap dividend payout ratio pada perusahaan manufaktur yang listed di Bursa Efek Indonesia. Hasil ini mendukung penelitian dari Nugroho (2004), namun kontradiktif dengan penelitian Chasana (2008), Amalia (2009), Latiefasari (2011), Difah (2011), Shitta (2011) yang menyatakan berpengaruh positif signifikan terhadap dividend payout ratio.

Dengan hasil ini maka $\mathrm{H}_{5}$ yang menyatakan bahwa Firm Size berpengaruh positif terhadap dividend payout ratio (DPR) diterima. 
INOBIS: Jurnal Inovasi Bisnis dan Manajemen Indonesia

Volume 1, Nomor 1, Maret 2018

Ronny Malavia Mardani

\section{Simpulan dan saran}

\section{Simpulan}

Berdasarkan uraian hasil penelitian dan pembahasan, maka dapat ditarik kesimpulan sebagai berikut:

Secara pasial variabel ROA berpengaruh positif signifikan terhadap DPR. Hasil ini menunjukkan bahwa manajemen perusahaan masih mempertimbangkan ROA dalam menentukan kebijakan dividen. Hal ini juga menjadi informasi yang sangat berguna bagi investor untuk memperhatikan ROA dalam menentukan investasi di perusahaan karena bila ROA meningkat maka akan meningkatkan dividen.

Sedang hubungan variable bebas lain yang terdiri dari Debt to Total Assets, Cash Ratio dan Firm Size terbukti juga memenuhi secara konsep teori, meskipun tidak signifikan. Sedang hubungan antara growth dengan kebijakan dividen tidak sesuai dengan yang dihipotesiskan. Hasil ini menunjukkan bahwa adanya pertumbuhan perusahaan akan meningkatkan peluang pembagian dividen.

\section{Saran}

Terhadap hasil analisis penelitian dan kesimpulan ada beberapa saran yang diharapkan mampu memberi sumbangan dalam bentuk ide atau pemikiran yang dapat diberikan sebagai berikut:

1. Perusahaan hendaknya lebih memperhatikan faktor-faktor mana sajakah yang berpengaruh dan perlu dipertimbangkan didalam kebijakan dividen.

2. Investor atau calon investor harus lebih memperhatikan informasi-informasi yang diberikan oleh perusahaan karena dengan adanya informasi tersebut maka dapat dimanfaatkan untuk mengambil keputusan yang tepat sehubungan dengan investasinya. Variabel ROA merupakan variabel yang berpengaruh dalam penelitian ini dengan beta standardized coeffisients sebesar 0,322.

3. Untuk peneliti selanjutnya, disarankan untuk menambah variabel yang dianalisis sehingga nantinya akan dapat mewakili keselurahan perhitungan dari analisis faktor-faktor yang mempengaruhi kebijakan dividen.

\section{Daftar pustaka}

Amalia, Fira Puspita, 2009, Analisis Faktor-Faktor yang mempengaruhi Kebijakan Dividen Payout Ratio (Studi Kasus Pada Perusahaan Yang Terdaftar Di Bursa Efek Indonesia Periode 2005-2007), tesis, tidak dipublikasikan, Semarang, Progam Pasca Sarjana Magister Manajemen, UNDIP.

Amalia, Shitta, 2011, Analisis Faktor-Faktor Yang Mempengaruhi Kebijakan Dividen Payout Ratio (Studi Kasus Pada Perusahaan Yang Terdaftar Di Bursa Efek Indonesia non Keuangan Periode 2005-2009)

Arilah, Muhammad Asril. 2009. Pengaruh Free Cash Flow, Profitabilitas, Likuiditas, dan Leverage Terhadap Kebijakan Dividen, Jurnal Keuangan dan Perbankan, Vol. 20. No. 1, pp. 78-87.

Basri dan Indriyo Gito Sudarmo. 2000. Manajemen Keuangan, Edisi 3. Yogyakarta: BPFE Yogyakarta.

Brigham, Eugene \& Joel Houston. 2015. Dasar-Dasar Manajemen Keuangan, Buku 2, Edisi 10. Jakarta: Salemba Empat. 
INOBIS: Jurnal Inovasi Bisnis dan Manajemen Indonesia

Volume 1, Nomor 1, Maret 2018

Ronny Malavia Mardani

Chasanah, Amalia Nur, 2008. Faktor-Faktor Yang Mempengaruhi Kebijakan Dividen Payout Ratio Pada Perusahaan Yang Listed di Bursa Efek Indonesia (Perbandingan Pada Perusahaan Yang Sebagian Sahamnya Dimiliki Oleh Manajemen Dan Yang Tidak Dimiliki Oleh Manajemen), Tesis, tidak dipublikasikan, Semarang, Progam Studi Magister Manajemen, Universitas Diponegoro Semarang.

Darminto. 2008. Pengaruh Profitabilitas, Likuidias, Struktur Modal dan Struktur Kepemilikan Saham Tehadap Kebijakan Dividen, Jurnal Ilmu-Ilmu Sosial, Vol. 20. No. 2.

Difah, Siti Syamsiroh, 2011, Analisis Faktor-Faktor yang mempengaruhi Kebijakan Dividen Payout Rato Pada Perusahaan Yang terdaftar di Bursa Efek Indonesia Periode Tahun 2004-2009.

Gujarati, Damodar. 2000. Ekonometrika Dasar. Jakarta: Erlangga.

Gujarati, Damodar. 2007. Dasar-Dasar Ekonometrika, Edisi Ketiga, Jilid 2. Jakarta: Erlangga.

Indriantoro, Nur dan Supomo Bambang. 1999. Metodologi Penelitian Bisnis. Edisi Pertama. Yogyakarta: BPFE UGM.

Jogiyanto. 1998. Teory portofolio dan Analisis Investasi. Yogyakarta: BPFE UGM.

Jogiyanto. 2008. Pedoman Survei Kuesioner, Mengembang Kuesioner, Mengatasi Bias dan Meningkatkan Respon. Yogyakarta: BPFE UGM.

Latifasari, Hani Diana, 2011,Analisis Faktor-Faktor yang mempengaruhi Kebijakan Dividen (Studi Empiris pada perusahaan manufaktur yang terdaftar di BEI Periode Tahun 2005-2009).

Marlina, Lisa dan Clara Danica. 2009. Analisis Pengaruh Cash Potition, Debt To Equity Ratio, dan Return On asset Terhadap Dividen Payout Ratio, Jurnal manajemen bisnis, Volume.2. No. 1, pp. 1-6.

Nugroho, Setya, 2004, Analisis Faktor-Faktor yang mempengaruhi Kebijakan Dividen pada perusahaan yang Listed di Bursa Efek Jakarta, Tesis, tidak dipublikasikan, Semarang, Progam Pasca Sarjana Magister Manajemen, UNDIP.

Riyanto, Bambang. 2001. Dasar-Dasar Pebelanjaan Perusahaan. Yogyakarta: BPFE.

Sudarsi, Sri. 2002. Analisis Faktor-Faktor yang mempengaruhi Kebijakan Dividen Payout Ratio Pada Industri Perbankan Yang Listed di Bursa Efek Jakarta, Jurnal bisnis dan Ekonomi.

Sunarto dan Andika kartika.2003. Analisis Faktor-faktor Yang Mempengaruhi Dividen kas di Bursa Efek Jakarta, Jurnal Bisnis dan Ekonomi.

Warsono, 1999. Manajemen Keuangan, Buku 1, keputusan Keuangan Jangka Panjang. Malang: UMM Press.

Weston, J. Fred \& Thomas E. Copeland. 1997. Manajemen Keuangan, Jilid Dua. Jakarta: Binarupa Aksara.

Widoadmodjo, Sawidji. 1996. Cara Sehat Investasi di Pasar Modal. Jakarta: PT Jurnalindo Aksara Grafika. 